\title{
Tectonics Activity and Volcanism Influence to the Garut and Leles Basins Configuration and the Implication on Environmental Geology
}

\author{
Iyan Haryanto ${ }^{1}$, Emi Sukiyah ${ }^{2}$, N. Nurul Ilmi $^{3}$, Y. A. Sendjaja ${ }^{4}$, E. Sunardi ${ }^{5}$ \\ 1, 2, 3, 4, 5 Department of Geosciences, Faculty of Geological Engineering, Padjadjaran University, Bandung-Sumedang Road km 21, \\ Jatinangor, Indonesia
}

\begin{abstract}
Garut and Leles basins are located in the Quaternary Volcanic mountain chain which was formed by the modern subduction. Both basins are similar to the Bandung Basin, with a different geological setting background. The Bandung Basin entirely bounded by fault structures, whilst the Garut and Leles basin are bordered by a combination of faults and Quaternary volcanoes. In this study, the morphological observation through DEM data set used to determine the fault occurrence and the relative age distribution of volcanic rocks derived from each of the volcanic cone body. Then, these data are used to analyze the historical geological process of both basins which has a connection with their geometry and position. These basins are classified as a tectonic basin which is controlled by two major northeast-southwest strike-slip faults. So then, the riedel shear system is applied to the center area in between these two faults which then produces the pull apart basin. Moreover, the second basin geometry show as a relatively ellipse geometry with the long axis trending of northeast-southwest.
\end{abstract}

Keywords: Garut Basin, Leles Basin, extensional basin, compressional tectonic regime, riedel shear

\section{Introduction}

Garut and Leles basins are located in the volcano chains which are formed from the modern subduction process (Figure.1). Other than those basins, there are many Quaternary basins in West Java which follow; Ciranjang Basin (Cianjur district), Cikijing Basin (Majalangka district), Ciniru Basin (Kuningan district), Wado depression zone (Sumedang district), Cimandiri valley (Sukabumi district) and Lembang Highland (Northern Bandung district).

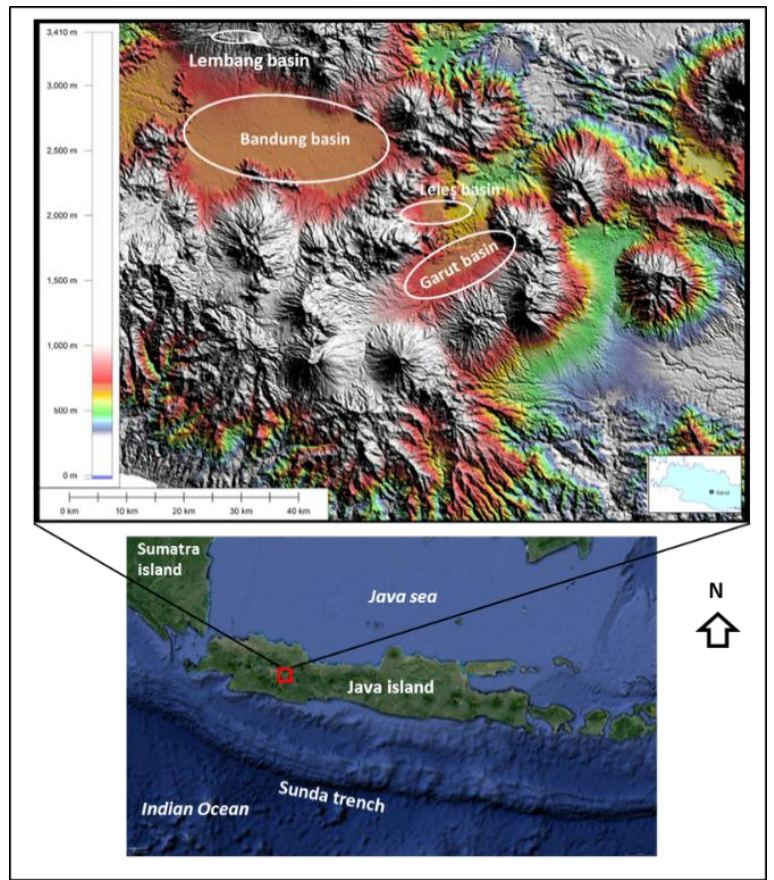

Figure 1: The location of basinal features which is related to the volcano morphology from Bandung area to Garut district and the modern subduction zone
The development of sedimentary basins in West Java mainly control by the fold structures and the morphological features of volcano itself. The main structural patterns in west java are east-west direction fold structures and they are followed by normal and strike-slip faults (tear faults) (Figure 2; [7]).

Lembang highland in northern Bandung are covered by volcanic hills. The southern part of Lembang highland is controlled by the Lembang normal faults where the northern part is limited by volcanic materials of Quaternary Tangkubanprahu eruption (Figure. 2). Furthermore, Cikijing basin (Majalengka district) predominantly resulted from pull apart system of Citanduy strike-slip fault, whereas Ciniru Basin (Kuningan district) mainly control by anticlinal collapse [7].

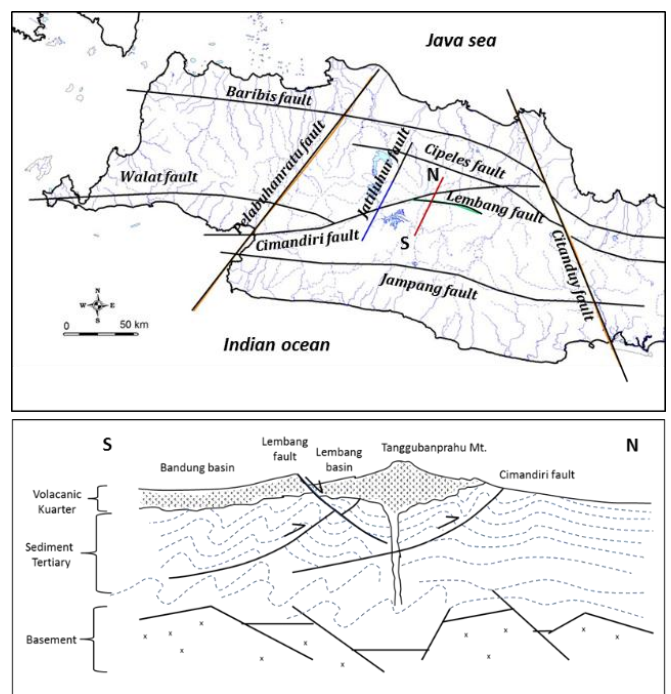

Figure 2: A. The regional structural pattern of West Java province. B. Lembang Highland occurrence is control by Lembang normal fault and Tangkubanprahu volcano [7]

Volume 6 Issue 1, January 2017

www.ijsr.net 


\section{International Journal of Science and Research (IJSR) \\ ISSN (Online): 2319-7064}

Index Copernicus Value (2015): 78.96 Impact Factor (2015): 6.391

The differences of each basinal development in volcano chain are the basis of the study, especially at Garut and leles basins.

\section{Methods}

The early stage of this study conducted morphological analyses from the remote sensing data set (DEM) and topography map. These used to determine the attitude and geometry of each basin and its relation with the ancient and modern volcanoes. Also, the presence of the fault system within the basins as well as the volcano development and the structural geology on the basis of its morphological geometry and the drainage system of the study area.

In order to constraint the major direction of fractures pattern, the analysis of structural lineament presented as a rosette diagram. Then, the fracture patterns are used to interpret the structural configuration of the study area.

The study is used the observation of morphological features as the qualitative aspect along with the calculation of sinuosity mountain from or Smf [9]. The Smf values are calculated from the ratio of the length of the mountain front along the valley which shows a break in slope and the straight-line length of mountain front [9], where the equation of Smf followed (Figure 3);

$$
S m f=L m f / L s
$$

Where:

Lmf = the length of the mountain front along the valley which shows a break in slope; Ls = the straight-line length of mountain front.

Furthermore, we then used the gravity data set in order to correlate the structures on the surface to the subsurface. These included determination of the reactivation of structural deformation which has a consequence to the morphological features of the youngest volcanic formations on surface area.

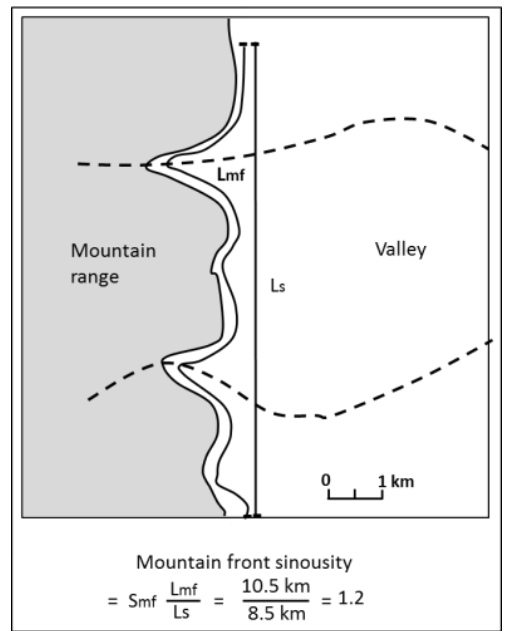

Figure 3: The illustration of the calculation of Sinuosity Mountain Front (Smf) [9]
The field work conducted on the areas which had been interpreted as fault zone and covered by primary volcanic and volcano-sedimentary rocks

\section{Result and Discuss}

\subsection{Physiogeography and Volcano morphology}

Physiogeoraphycally, Garut and Leles basins are located on the Bandung Zone and The Southern Mountain Zone [17]. Moreover, these basins are situated on the volcanic arc region as a consequence of recent subduction process.

The Garut basin is cover up by the Pleistocene volcano systems and Quaternary active volcanoes, which follow; Galunggung, Kracak, Cikurey, Papandayan, Darajat, and Guntur. Furthermore, the Leles basin is bounded by the recent volcano systems (e.g. Guntur, Mandalawangi, Kaledong and Haruman) and the volcanic hills which resulted from the eruption of Pleistocene volcanoes.

In general, the morphology of the old volcano formations nowadays does not show their initial configuration which are formed as a cinder cones and showed a rough topographical textures. These conditions indicate that most of volcanoes are affected by the structural deformation such as faults and fractures. Each volcano in Garut and Leles show rough and soft topographical textures. These can be indicated the formation of the volcanoes where the rough topography textures suggested old volcano configuration, whether the soft shows the youngest volcanoes construction (Figure 4).
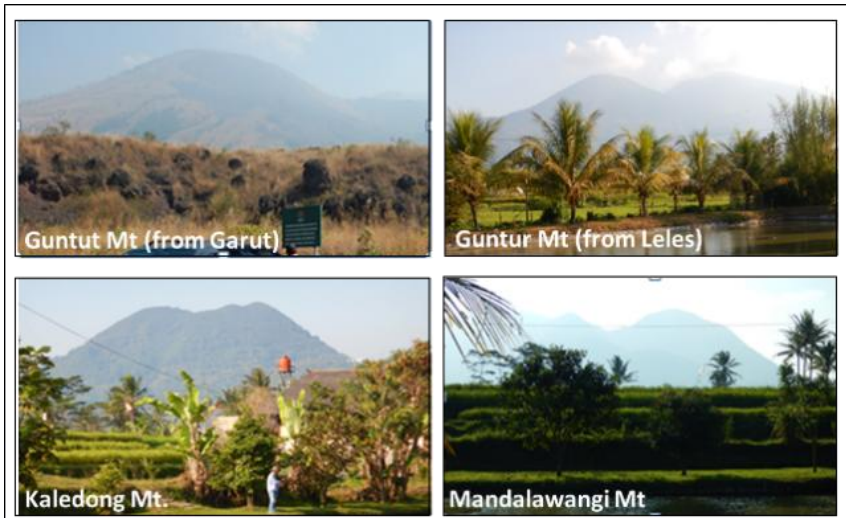

Figure 4: Photograph showing the morphological features of an active volcano which is form as a cinder cone structure

The volcanoes chain in Garut basin; the cinder cone structures are presence from the Cakrabuana (northeast) to the Papandayan volcano (southwest). However, the topographical textures are recognized to be softer to the southeast. These possibly related to the development of volcanism that shifted to the southeast area (Figure. 5)

The strip old volcanic hills are widespread in the north and northwest. This hilly pathway acts as a barrier between Bandung Basin, Garut Basin and Leles Basin. Garut Basin and Leles Basin are separated by old volcanic hills and Mount Guntur is still active.

Volume 6 Issue 1, January 2017 www.ijsr.net 


\section{International Journal of Science and Research (IJSR) \\ ISSN (Online): 2319-7064}

Index Copernicus Value (2015): 78.96 | Impact Factor (2015): 6.391

\subsection{Volcanism}

The formation of Garut and Leles basins are situated on the volcanic arc that associated the modern subduction on the southern Java [4][12][3].
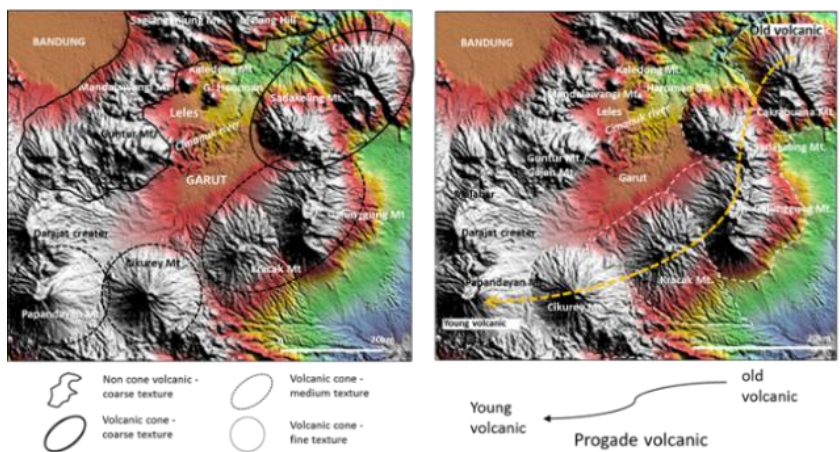

Figure 5: A. The difference in texture shows the establishment of the volcanoes. B. The growth of volcanoes from the northeast toward the southwest

During Pliocene - Pleistocene, the massive eruption of several volcanoes around the Java Island overlie the oldest stratigraphy formations. These included the study area, where the crop out formation covers up by volcanic material (Figure. 6)

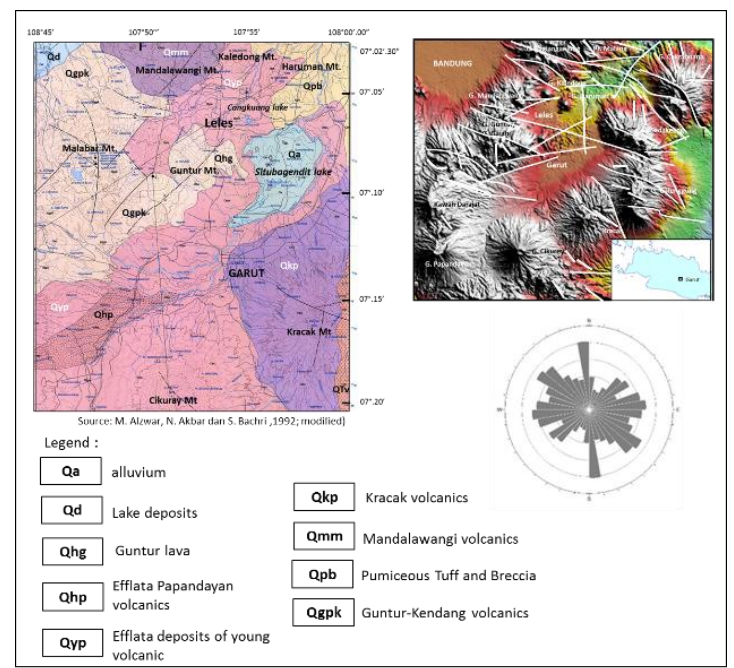

Figure 6: The detailed geological map of Garut and Leles included the structural patterns and the distribution of Quaternary volcanic rock which is overlied the older stratigraphy formation [1] [11].

The volcanism on Garut and Leles basins are still remain until nowadays, since the Pliocene, which is resulted multiple eruption from several volcanic center. This is evidenced from rock samples taken below the surface through geothermal drilling by the oil company (Pertamina) in Gunung Wayang. The $\mathrm{K}$ - Ar dating suggested the age of volcanic rocks of 12 $\pm 0.1 \mathrm{My}$, where the surface rocks $0.49 \pm 0.01 \mathrm{My}$. As a comparison, the volcanic ages from Malabar-Papandatan display the ages of $4.32 \pm 0.004$ My until 2.62 \pm 0.03 My and the outcrop samples of the Pleistocene age [12][13]. Moreover, the ages of volcanic rocks are similar to the rocks from Soreang-Banjaran (Southern Bandung), where the ages of the Late Pleistocene.

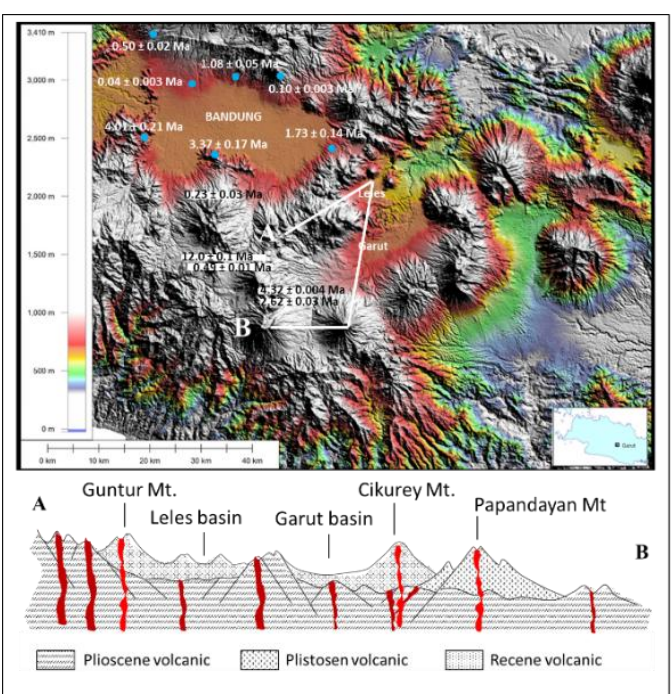

Figure 7: Distribution map of the $\mathrm{K}-\mathrm{Ar}$ ages which show the evidenced of multiple eruption at the Pliocene -

Pleistocene.

The evidence of multiple eruptions also can be recognized from the distribution of volcanic eruption of Guntur volcanoes which overlie the ancient volcanic hill.

\subsection{Tectonic and structural geology}

The structure interpretation based on DEM, there are several lineaments showing fault structure with an east-west, northwest-southeast and northeast-southwest directions (Figure 6). Furthermore, from the subsurface interpretation, using gravity method, some of the structures are similar to the structures on the surface. Where it shows a reactivation of old faults in the bedrock that affects the structural pattern on the surface.

Underneath the Leles and Garut basin, two fault lines were founded which are parallel to the horizontal direction of northeast-southwest. These fault lines control the distribution of young volcanoes in both basins. In the Garut are, horizontal faults control the distribution of volcanoes from Gunung Cakrabuana to the Gunung Papandayan. In the western part, the fault lines control the distribution of old volcanoes which also acts as a border between the Bandung and Leles Basin.

The geometry of the Garut and Leles Basin is relatively ellipsoidal, with the long axis trending northeast-southwest. Both basins are developing by two strike slips that are parallel to each other. Referring to the Riedel shear model of the structure, reactivation of both faults formed secondary structures that are E- extensional; P-shear and X-shear [16]. Leles and Garut basin was formed by the E- extensional components (Figure 8). These tectonic that differs the orientation of and Leles and Garut Basin with other basins in West Java which generally has an east-west trend [15].

\section{Volume 6 Issue 1, January 2017 www.ijsr.net}




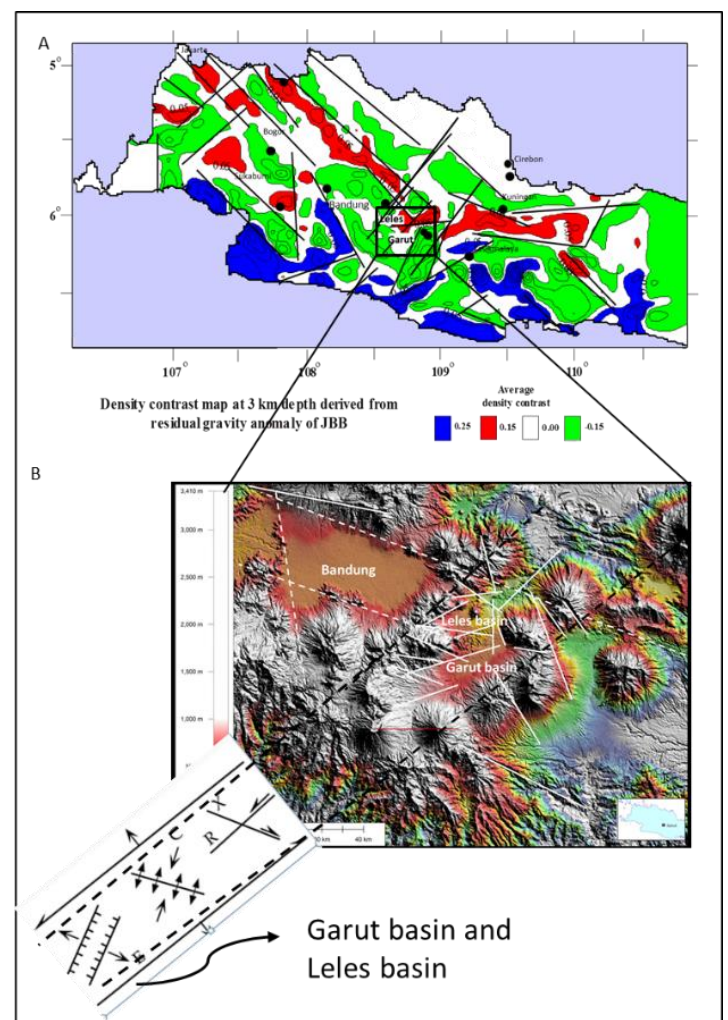

Figure 8: A. The gravity data suggests two pairs of faults that are parallel to the direction of NE-SW. B. Leles and

Garut basin formed by the Riedel shear system [14].

Magnetotellurics (MT) measurement under Leles Basin (Figure 9), shows there is a graben in the basement. The data shows that Leles depression correlates formation of the graben in the bedrock underneath. These conditions indicate the existence of old faults reactivation that affects the topography and structure patterns.

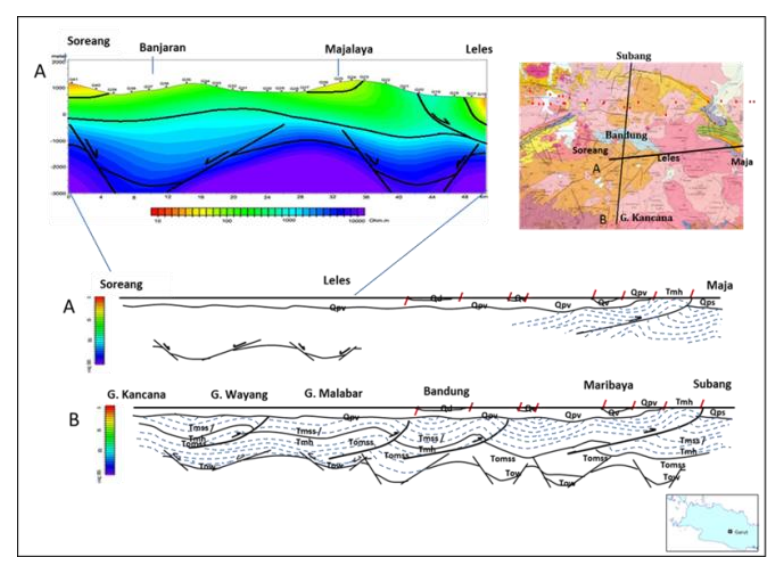

Figure 9: Graben under the Leles Basin shows a fault reactivation on the basement [5] and modified from [14]

The reactivation of old faults in the basement occurs with different sharpness systems. The pre-rift episode (Early Tertiary), where the graben was formed under extensional affirmation system [10][3] where sedimentation process also began until Pleistocene [7]. Late Tertiary period, old fault reactivated by the compressional stress, which all Tertiary rocks in Java were lifted, folded and faulted (Figure 9). This tectonic episode causes the Bandung, Garut and Leles as the Java geanticline peak zone [17][6]. By early Quaternary, the tectonic compressional stress decreased, causing the collapse of the Java Geanticline. The collapse of large anticline, formed basins among the mountains. At this stage, the Garut and Leles Basin occurred by two interrelated reasons, firstly as a result of reactivation of old faults which form the Riedel shear; and the second as a result from the anticlinal collapse.

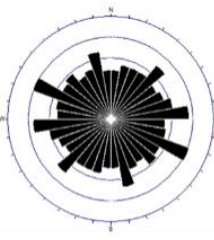

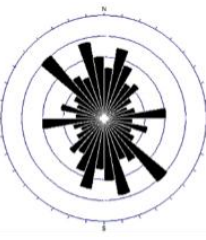

B

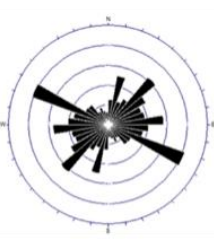

C
Figure 10: A. Rosette cracks of active volcanoes, B. rosette cracks of young volcanoes affected by geological structure,

C. rosette cracks of old volcanic hills (drawn by Aji

Dermawan).

Fractured bed on fault structures are path for magma to descends to the surface which eventually forming a volcanic range as occurred in Garut and Leles. In this case, a row of young volcanoes and active volcanoes in the south of Garut basin, controlled by a pair of horizontal faults trending northeast-southwest. The same condition also occurs in a series of old volcanoes acting as a basin border between Leles and Garut (Figure 8).

The measurement results showed that fracture pattern of active volcanoes are radier, showing that geological structure has not affected. In the young active volcanoes which generally are radier to semi radier pattern, show little of the influence of geological structure, and the old volcanoes are generally semi-radier to non-radier, showing the influence of geological structures (Figure 10).

Indications of fault structure are also shown by drainage pattern in the area. Reflected in the shape of Cimanuk river caused by faults. Cimanuk as the main river has many bends which the river bends position coincides with the alignment of the slopes valley from Sangianganjung Mt, Malang hill, and Cakrabuana Mt. Faulting indications had shown by narrow, long, straight, asymmetry and steep valley. Another indication is drainage patterns of the old volcanic which are rectangular and trellis. Both of these patterns indicate the effect of geological structure [8]

\subsection{Neo-tectonic}

Tectonically, Leles and Garut are in an active zone. This is shown by many active volcanoes with relatively frequent earthquake events founded. The BMKG seismic data reported the latest earthquake in Garut $(101 \mathrm{~km}$ south west of the city of Garut) took place on 6 April 2016, with a magnitude of 6.1 Richter scale with the epicenter at a depth of $10 \mathrm{~km}$.

Tectonically active of research he is also shown by the Smf values taken from several locations (Figure 10). With a scale from low to high.

Tectonically active evidenced also by the discovery of slicken side on volcanic breccia as a results of Guntur Mt last

\section{Volume 6 Issue 1, January 2017 www.ijsr.net}




\section{International Journal of Science and Research (IJSR) \\ ISSN (Online): 2319-7064}

Index Copernicus Value (2015): 78.96 | Impact Factor (2015): 6.391

eruption. Furthermore, soft sedimentary structure in mudstone believed to be the ancient Lake deposits (Figure 11). Graben that took place under an extensional stress deepens both basins above. Along with the fault reactivation volcanism and magmatic activities increased forming a range of volcanoes that also acts as basin borders.

While the plate still subduction, the continuity of fault reactivation caused young volcanic body faulted, as happened in the Cakrabuana volcano complex. Active tectonics until present day, shown by the Cimanuk meandering river system affected by fault structures.

\subsection{Environment Impact and Geology Resource}

Geological conditions in Garut and Leles area gives both positive and negative impacts to the community.

Negative impacts:

1) Geologically, Garut and Leles are currently on an active tectonic zone, causing both areas are in an earthquakeprone zones. Earthquakes often occur, causing casualties and material losses, latest earthquake occurred on August $10^{\text {th }} 2015$, causing a number of injured people hit by collapsed buildings.

2) Most of the morphology and Leles Garut region, in the form of volcanic hills with slope moderate to steep, since the rocks are generally not well consolidated, thus the area are also threatened by landslides, especially during the rainy season or due to earthquakes. Several major landslides have occurred in Nagrek area, causing disruption of train connection from Bandung to Garut. Other events like avalanche or debris fall also happened in the Kadungora-Leles area.

3) Gunung Guntur which is one of the active volcano that lies as a boundary Garut and Leles basin, at one time can again erupt causing great damage impact to the surrounding community. Especially with the current rapid population growth around the eastern slope are now as a local tourist area.

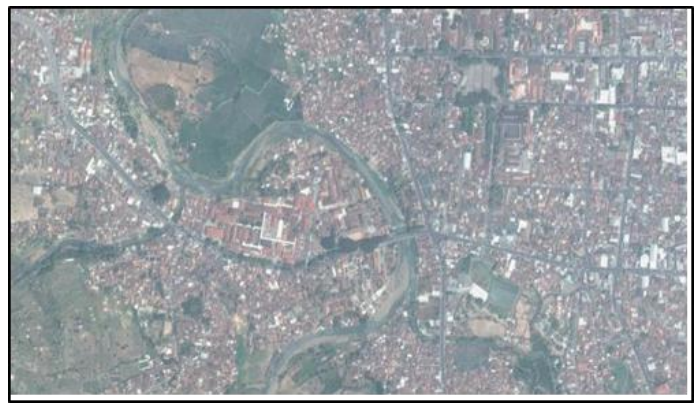

Figure 11: Satellite image showing Cimanuk River flowing inside the Garut main city

4) Floods also often occur in the Garut basin. The spacious cathment area of the Cimanuk river that flows inside the main City (Figure 11). Large flash flood recently occurred on September 21st, 2016 with numerous casualties.

Positive impacts:

1) Garut and Leles have many active volcanoes, such as Mt. Guntur, Mt. Patuha, Mt. Malabar and Papandayan. Among these volcanoes have been used as geothermal energy resource, tourist areas, and agricultural development (Figure 12).

2) Volcanic rocks from the volcanoes are known as high porosity and permeability rocks, which are good reservoir for natural waters. Water from these reservoirs is good in quality and friendly use.

3) Weathered volcanic rocks surrounding Garut and Leles area acts as arable land. Therefore most of the land are good for agricultural and plantations area.

4) Morphology of Garut and Leles basin are plain, this feature used as the center of government, residential and agricultural land like in any other area (Bandung basin [2]).

5) Rich in quarry materials ( $\mathrm{C}$ type) reserves, mainly as raw material for infrastructure, building roads and also contains economical metallic minerals, as a product from the magmatic and volcanism surrounding.
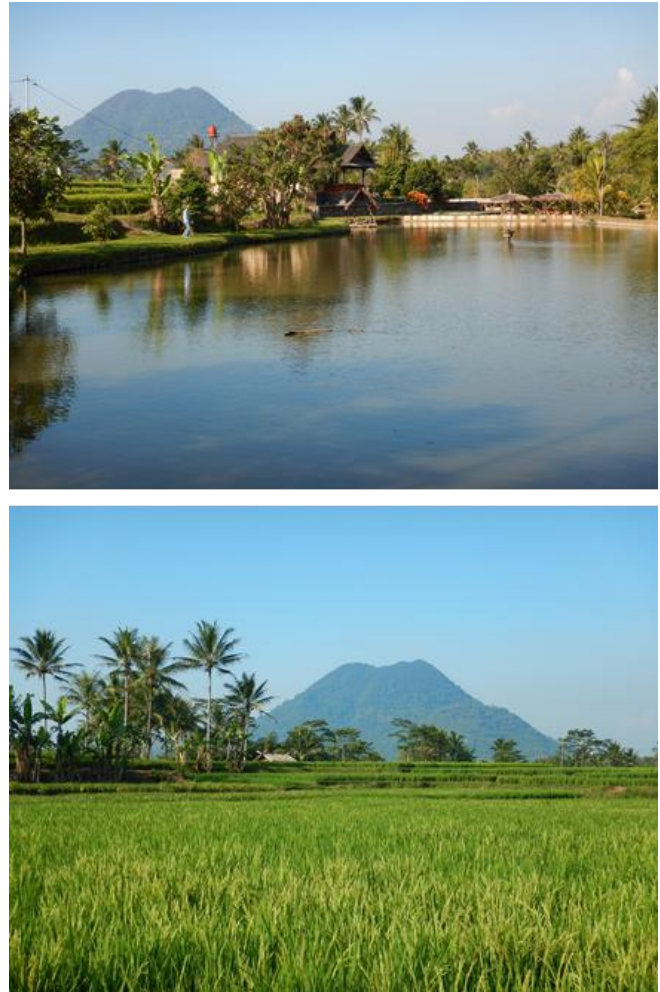

Figure 12: Versatile land with beautiful scenery of Leles area is best for tourism and agriculture use (Photo by Haryanto, 2015).

\section{Conclusion}

Garut and Leles basin are situated between mountains formed by Riedel shear system. The ongoing process of the area makes these controlled by several volcanic cones.

Geologically, the Garut and Leles area are in an active tectonic zone, the plains are surrounded by volcanic hills morphology with a moderate to steep slope, where most of the rock comprising the area is not well consolidated. With these geological conditions, even though Garut and Leles tend to have hazards such as; earthquakes, landslides and floods, these two regions also have potentials, like; active volcanoes surrounding which some are utilized as a thermal power plant (geothermal), weathered volcanic rocks as fertile

\section{Volume 6 Issue 1, January 2017




\section{International Journal of Science and Research (IJSR) \\ ISSN (Online): 2319-7064 \\ Index Copernicus Value (2015): 78.96 | Impact Factor (2015): 6.391}

soil for agricultural and plantations, subsurface large water resources and quarry resource supporting infrastructure development, and suspected precious metal resources.

\section{Acknowledgements}

This research is partly funded by the Academic Leadership Grant (ALG) 2015-2019 provided by University of Padjadjaran. We also would like to thank the students: Aji Dermawan, Ikhtiar Dwi Wardhana dan Choiril Firmansyah (Faculty of Geology, Unpad) who were involved in this research project.

\section{References}

[1] Alzwar, M., Akbar, N., and Bachri, S., "Geological Map of Garut and Pameungpeuk Sheet, Java," 1:100,000 scale, Puslitbang Geologi, Bandung, 1992.

[2] Bronto, S. and Hartono, U., "Potensi Sumber Daya Geologi di Daerah Cekungan Bandung dan sekitarnya", Jurnal Geologi Indonesia, 1 (1), pp.9-18, 2006.

[3] Hall R., Clementss B., Smyth H.R. \& Cottam M.A., "A New Interpretation of Java's Structure", Proceeding Indonesia Petroleum Association, 31st Annual Convention, 125-181, 2007.

[4] Hamilton, W, Tectonics of the Indonesian Region: Geological Survey Professional Paper 1078, US. Government Printing Office, 1979.

[5] Handayani, L., Kamtono and Wardhana D.D., Extensional Tectonic Regime of Garut Basin based on Magnetotelluric Analysis. Indonesian Journal of Geology, Vol. 8 No. 3, pp. 127-133, 2013.

[6] Haryanto, Iyan. 2013. Struktur Sesar di Pulau Jawa Bagian Barat berdasarkan Hasil Interpretasi Geologi. Bandung: Bulletin of Scientific Contribution, Volume 11, Nomor 1, pp. 1-10, 2013.

[7] Haryanto, Iyan, 2014, Tectonic evolution of Western part of Java in Caenozoicum, dissertation, Padjadjaran University, pp.50, 2014.

[8] Howard, Arthur David, Drainage Analysis in Geologic Interpretation: A Summation. The American Association Petroleum Geologist Bulletin, Vol.51,No.11, pp. 22462259, 1967.

[9] Keller, E.A. and Pinter N., Active Tectonics (Earthquake, Uplift and Landscape). Prentise Hall, Upper Saddle River, New Jersey 07458, 1996.

[10] Martodjojo S, Evolusi Cekungan Bogor, Jawa Barat, Tesis Doktor, Pasca Sarjana ITB. (Tidak dipublikasikan), 1984.

[11] Smith, W.H., and Sandwell, D.T., Global seafloor topography from satellite altimetry and ship depth sounding. Science, 277, pp.1956-1962, 1997.

[12] Soeria-Atmadja, R., Maury, R. C., Belon, H., Pringgoprawiro, H., Polve, M., dan Priadi, B., "Tertiary magmatic belts in Java," Journal of South East Asian Earth Science, 9, pp.13-27, 1994.

[13] Sunardi, E. dan Koesoemadinata, R.P., "New K-Ar Ages and The Magmatic Evolution of The Sunda-Tangkuban Perahu Volcano Complex Formations, West Java, Indonesia", In Proceedings of the 28th Annual
Convention IAGI, Jakarta, 30 Nov. - 1 Des., 1999, p.6371, 1999.

[14] Sunardi, E., Kontrol struktur terhadap penyebaran batuan volkanik Kuarter dan gunungapi aktif di Jawa Barat, Bulletin of Sci. Contribution, volume 12, hal. 123-127, 2014.

[15] Sunardi, E., Reaktivasi sesar tua dan pengaruhnya terhadap pembentukan struktur geologi dan cekungan Kuarter di daerah Bandung-Garut, Bulletin of Sci. Contribution, Volume 12, hal. 63-68, 2014.

[16] Wilcox, R .E., Harding, T. P. \& Seely, D. R, Basic wrench tectonics, American Association of Petroleum Geologists (AAPG) Bulletin, Vol. 57, No. 1, pp. $74-$ 96, 1973.

[17] Van Bemmelen, R.W., The Geology of Indonesia Vol. IA: General Geology of Indonesia and Adjacent Archipelagoes, Martinus Nijhoff, The Hague, Netherlands, 1949

\section{Author Profile}

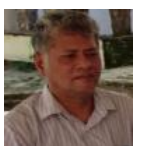

Iyan Haryanto recieved the B.S in Geology from Universitas Padjadjaran (1983), Master in Geology from ITB (1999), and Doctor in Geology from Universitas Padjadjaran (2014). Tectonis and basin analysis are his major researh interest.

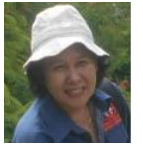

Emi Sukiyah received the Engineering degree in Geology from Padjadjaran University in 1993, Master degree in 2000 from Postgraduate program of Geological Engineering - Institute of Technology Bandung, and Doctor degree in 2009 from Postgraduate program of Geological Engineering - Padjadjaran University. Since 1997 as a lecturer in the Faculty of Geological Engineering - Padjadjaran University, Bandung, Indonesia. Fields of research: Remote sensing application in the field of geology, tectonic geomorphology, renewable energy, the GIS application forspatial analysis, erosion modeling

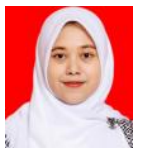

Nisa Nurul Ilmi received the S.Si (equal to the B.Sc) in chemistry from Universitas Padjadjaran in 2011. She then pursued a Master degree in University of Newcastle upon Tyne, UK specializing in Petroleum Geochemistry in 2012 and received her M.Sc in 2013. She currently stays in Indonesia and becomes a lecturer in Geological Faculty, Universitas Padjadjaran.

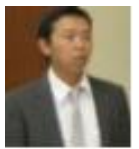

Yoga Andriana S. received the S.T. (equal to the B.Sc) in geology from Universitas Padjadjaran in 1997. He then pursued a Master degree in Shimane University, Matsue-Japan specializing in Geochemistry and received his M.Sc in 2001. Doctor degree in 2009 from Shimane University. He currently stays in Indonesia and becomes a lecturer in Geological Faculty, Universitas Padjadjaran

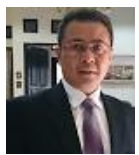

Edy Sunardi received the Ir. (equal to the B.Sc) in geology from Universitas Padjadjaran in 1985. He then pursued a Master degree in Earth Institute, Free University Brussels Belgia. Doctor Degree from Department of Geoscience, Osaka City University Japan in 1997. $\mathrm{He}$ currently stays in Indonesia and becomes a professor in Geological Faculty, Universitas Padjadjaran 